\begin{tabular}{|l|l|l||}
\hline \multicolumn{2}{|c|}{ PublisherInfo } \\
\hline \hline PublisherName & $:$ & BioMed Central \\
\hline \hline PublisherLocation & $:$ & London \\
\hline \hline PublisherImprintName & $:$ & BioMed Central \\
\hline \hline
\end{tabular}

\title{
ErbB2 and cell cycle control
}

\begin{tabular}{|l|l|l||}
\hline \multicolumn{2}{|c|}{ ArticleInfo } \\
\hline \hline ArticleID & $:$ & 3707 \\
\hline \hline ArticleDOI & $:$ & $10.1186 /$ bcr-2000-66670 \\
\hline \hline ArticleCitationID & $:$ & 66670 \\
\hline \hline ArticleSequenceNumber & $:$ & 73 \\
\hline \hline ArticleCategory & $:$ & Paper Report \\
\hline ArticleFirstPage & $:$ & 1 \\
\hline \hline ArticleLastPage & $:$ & 4 \\
\hline \hline & & RegistrationDate : 2000-4-25 \\
\hline ArticleHistory & $:$ & OnlineDate \\
\hline ArticleCopyright & $:$ & Current Science Ltd2000-4-25 \\
\hline \hline ArticleGrants & $:$ & \\
\hline \hline ArticleContext & $:$ & 1305822 \\
\hline \hline
\end{tabular}




\section{Keywords}

c-Myc, MAP kinase, PI3 kinase, p2 $7^{\text {kip1 }}$, single chain antibody

\section{Introduction}

The ErbB2 RTK is overexpressed in up to $30 \%$ of breast tumours, where it correlates with poor prognosis. No soluble ErbB2 ligand has been identified. However, ligand binding to other ErbB family members induces heterodimerization and activation of ErbB2. To date, the mechanism(s) by which oncogenic ErbB2 impinges on proliferation, and the cell cycle components involved in the mechanism(s), have not been identified. In order to study ErbB2-dependent proliferation, the receptor has been functionally inactivated in a breast carcinoma cell line using an intracellularly expressed, endoplasmic reticulum (ER)-targeted single chain antibody (scFV-5R).

\section{Aims}

To identify the crucial cellular components affected by elevated ErbB2 expression and to understand how loss of ErbB2 function impacts on intracellular signalling pathways and on regulators of the cell cycle.

\section{Comments}

ErbB2 plays a critical role in the proliferation of tumour cells which overexpress the receptor tyrosine kinase (RTK), although its precise functions remain unclear. This paper examines ErbB2-dependent proliferation by use of a vector which efficiently downregulates the receptor in an overexpressing cell line. ErbB2 and ErbB3 are seen to function in unison to stimulate proliferation via a number of signalling pathways, with c-Myc as a central figure in the cascade. Although there are no clinical data correlating ErbB2 and c-Myc expression levels, the authors suggest that such a link may exist.

\section{Methods}


$\mathrm{SKBr} 3$ breast carcinoma cells were transfected with the inducible scFV-5R construct. Protein detection was analysed using immunoprecipitation and immunoblotting techniques. Cell cycle analysis was carried out by flow cytometry.

\section{Results}

Overexpression of the receptor tyrosine kinase ErbB2 plays a critical role in the proliferation of tumour cells, although downregulation of ErbB2 by scFV-5R led to a decrease in ErbB3 tyrosine phosphorylation, and a parallel decrease in association between ErbB3 and the p85 subunit of PI3K (phosphatidylinositol 3-kinase). Targets of multiple downstream signalling pathways including the extracellular signal-regulated kinases ERK1/ERK2, Akt/PKB (protein kinase B) and p70 ${ }^{\mathrm{S} 6 \mathrm{k}}$ were also reduced after $\mathrm{scFV}-5 \mathrm{R}$ induction. Induction of $\mathrm{scFV}-5 \mathrm{R}$ expression led to an accumulation of SKBr3-c16 cells in the G1 phase of the cell cycle. An associated decrease in pRb levels was also observed, which correlated with a drop in cyclin-dependent kinase (CDK) 2 activity. Immunoblotting of CDK inhibitory proteins indicated that, of the INK4 and Cip/Kip CH1 family members, only p27 Kip1 appeared to be associated with cyclin E/CDK2 activity. c-Myc protein and mRNA levels decreased after scFV-5R induction, as well as after treatment with inhibitors of ErbB2, PI3 kinase, and MEK1/2 (mitogen-activated protein kinase/extracellular signal-regulated kinase kinase). Ectopic expression of cMyc led to an increase in cyclin D and CDK2 activity and resulted in partial G1 rescue.

\section{Discussion}

Loss of functional ErbB2 in the overexpressing SKBr3 breast tumour cell line led to decreased activity of ErbB3, MAP kinase and PKB/Akt, suggesting that active ErbB2/ErbB3 dimers are necessary for sustained activity of these kinases. The cells entered a G1 arrest, a result of a reduction of c-Myc and $\mathrm{D}$ cyclins releasing sequestered $\mathrm{p} 27^{\mathrm{Kip} 1}$ to complex with and inhibit CDK2 activity. The critical role of c-Myc in ErbB2-mediated oncogenicity is emphasised by the prevention of normal p2 $7^{\mathrm{Kip} 1}$ control of cyclin $\mathrm{C} / \mathrm{CDK} 2$. 


\section{References}

1. Neve RM, Sutterl\&uumlty H, Pullen N, Lane HA, Daly JM, Krek W, Hynes NE: Effects of oncogenic ErbB2 on G1 cell cycle regulators in breast tumour cells. Oncogene. 2000, 19: 1647-1656. 